\title{
Review of Modern Pastoralism and Conservation: Old Problems, New Challenges edited by Troy Sternberg and Dawn Chatty
}

\author{
Katherine Homewood
}

\author{
Correspondence: \\ k.homewood@ucl.ac.uk \\ University College London, Gower \\ Street, London WC1E 6BT, UK
}

\author{
Book details \\ Sternberg, T and Chatty, D (eds.): Modern Pastoralism and Conservation: Old \\ Problems, New Challenges. Cambridge: White Horse Press, 2013. Xii + 210 pages, \\ ISBN 978-1-874267-74-4 \\ Keywords: Canada First Nations, Central Asia, China, Kenya Maasailand, Oman, Sahel, \\ Sudan, Tibetan Plateau, Niger WoDaabe
}

The 16th Congress of the International Union of Anthropological and Ethnological Sciences was scheduled to take place in China in the summer of 2008. The devastating Sichuan earthquake meant the meeting had to be postponed, but it took place the following year in Kunming. This book is a collection of papers presented at the panels reconvened there by the Commission for Nomadic Peoples.

Perhaps in keeping with its troubled inception, the book takes a sombre tone. Khazanov, whose lifetime achievement was honoured at the meeting, opens the collection with a political-historical overview of twentieth-century pastoralism that is both breathtaking in scope and unremittingly bleak in outlook. Following Khazanov's longue durée view of the trajectories of pastoralism under communist and capitalist systems, most of the papers explore the decline of customary pastoralism in nations keen to modernize. The 'Conservation' of the title takes the broadest sense. In places, it refers to wildlife conservation (Chatty on Oman) or broad environmental policies (Yeh; Foggin and Zhaxi on western China/Tibet), but perhaps more generally it implies retention and resilience - or conversely and overwhelmingly, loss - of customary practices and lifeways. These papers chart political-economic and political-ecological maneuverings that lead to contentious, often forced, sometimes violent, always painful transitions, documented at levels ranging from the local (Kronenburg Garcia on Kenya Maasailand) or local/national (Chatty on Oman) to the playing out of marginalization and displacement on staggering scales (Mezhoud and Oxby on Sahel and Sudan; Sternberg, Yeh, Foggin and Zhaxi on Central Asia, western China/Tibetan Plateau and Canadian First Nations).

There are a couple of more positive notes. Moiko's heartening cameo of Ol Kirimatian in Kenya Maasailand portrays the survival of a resilient, consensus-based communal system in the face of pressures to privatize. Krätli's sensitive account

(c) 2013 Homewood; licensee Springer. This is an Open Access article distributed under the terms of the Creative Commons Attribution License (http://creativecommons.org/licenses/by/2.0), which permits unrestricted use, distribution, and reproduction in any medium, provided the original work is properly cited. 
explores the depth and richness contained in customary WoDaabe knowledge of livestock lineages, cattle condition and mobility underpinning pasture selection. Chatty documents the thoughtful, far-sighted, strategic responses of the marginalized Harasiis to national and international pressures to displace them in the name of Omani wildlife conservation. Sternberg outlines an agenda for research in the still poorly known, but rapidly transforming, Mongolian pastoral rangelands.

Overall though, this collection's message is consistently one of the spiraling decline of mobile pastoralism, whether through economic forces of privatization (Kronenburg Garcia); land and green grab (Mezhoud and Oxby on Sahel and Sudan; Chatty on Oman) or through political-economic/ecological suppression of mobile pastoralism and deliberate cultural genocide (Yeh; Foggin and Zhaxi on western China/Tibetan Plateau and Canada). These perceptive analyses of the way ecological modernist policies are failing to deliver and of the likely outcomes of policies of dislocation and sedentarisation should give policymakers food for thought.

The great weight and authority of Khazanov's synthesis, and the detailed case studies that follow, make for a sobering realism in charting the global trajectory of mobile pastoralism. This picture is not so much challenged but perhaps leavened by other recent edited collections in the field, which document innovation, resilience and positive transformations (e.g. Catley et al. 2012) in the face of environmental and sociopolitical challenges, while acknowledging the drastic impacts of global forces. Within that wider field, the present collection will be of real interest to development professionals, researchers and students of pastoralist systems in arid and semi-arid lands around the world, whether tropical, temperate or boreal. It is perhaps not too much to hope that the lessons it sets out and the predictions it makes as to the unfolding impacts of present policies, whether in Africa, the Middle East, Central Asia or western China, will reach the attention of policymakers and have some effect in moderating the most counterproductive and destructive state and international agency policies and practices.

Competing interests

The author declares that she has no competing interests.

Authors' information

$\mathrm{KH}$ is Professor of Human Ecology in the Anthropology Department at University College London.

Received: 5 June 2013 Accepted: 6 June 2013

Published: 28 July 2013

Reference

Catley, A, J Lind, and I Scoones (eds.). 2012. Pastoralism and development in Africa: Dynamic change at the margins. Abingdon: Routledge.

doi:10.1186/2041-7136-3-17

Cite this article as: Homewood: Review of Modern Pastoralism and Conservation: Old Problems, New Challenges edited by Troy Sternberg and Dawn Chatty. Pastoralism: Research, Policy and Practice 2013 3:17. 